\title{
ENHANCHING STUDENT'S MEMORIZATION SKILL OF HOLY QUR'AN TROUGH THE INTEGRATED TAHFIDZ PROGRAM IMPLEMENTATION IN POST PANDEMIC CONTEXT
}

\author{
Pepen Supendi $^{1}$, Nia Kurniawati ${ }^{2}$, Muhammad Sofyan ${ }^{3}$, Kresna Dewi Mulyana ${ }^{4}$ \\ ${ }^{1}$ Islamic Education Management, Tarbiyah and Teachery Faculty, State Islamic University of \\ Bandung, Indonesian \\ ${ }^{2}$ English Education, Tarbiyah and Teachery Faculty, State Islamic University of Bandung, \\ Indonesian \\ ${ }^{3,4}$ Teacher's Islamic Education of Elementary School, Tarbiyah and Teachery Faculty, State \\ Islamic University of Bandung, Indonesian \\ supendi_p@uinsgd.ac.id
}

Received: June $25^{\text {th }}, 2021$, revisied: July $2^{\text {nd }}, 2021$, published: September $30^{\text {th }}, 2021$

\begin{abstract}
The purpose of this paper implementation of the tahfiz program in MI Terpadu Ar-Rifqi Cileunyi district for the 2020/2021 academic year; Inhibitor and backups of the tahfiz program in MI Terpadu Ar-Rifqi Cileunyi district for the 2020/2021 academic year; Tahfiz program effectiveness in improving rote at the MI Terpadu Ar-Rifqi Cileunyi district for the 2020/2021 academic year. The study involves a qualitative approach with a type of case study. The method used is a qualitative descriptive method. Data is obtained from observation, interview and documentation and then analyzed by data reductin, data display and conclusions drawing nad verification. Studies have found that include the tahfiz program goals, teachers tahfiz, tahfiz materials, tahfiz methods, memorizing the Qur'an color block, talaqqi and muraja'ah, an evaluation of daily, weekly and semester assessments and the supporting and inhibiting factors for the implementation of the tahfiz program at the MI Terpadu Ar-Rifqi. Of the increased aspects of surah that memorized by learners, the effectiveness of tahfiz programs falls into highly effective categories. According to the tahfiz materials, the effectiveness of tahfiz programs is highly ineffective.
\end{abstract}

Keywords: memorizing the Qur'an; Tahfiz program; Tahfiz Al-Qur'an

\section{Introduction}

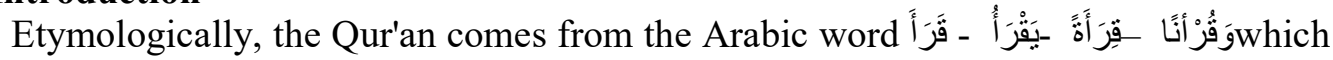
means to collect or collect (Syarbini \& Jamhari, 2012). Meanwhile, in terms of terminology, the Qur'an is literally interpreted as "the words of the eternal God, through the intermediary of the angel Gabriel, the revelation of the Qur'an to the Prophet Muhammad, contained in the Mushaf which was conveyed with mutawatir, acting as a guide for human life, as well as being a source of guidance for mankind. things of worship for those who read it" (Hitami, 2012).

The first and foremost guideline for all Muslims is the Qur'an, because the Qur'an was revealed by Allah. to mankind as a guide to achieving a peaceful, prosperous life in this world and the hereafter (Drajat, 2017). The Qur'an is the answer to every question of mankind, so the Qur'an is very important to learn because the Qur'an is a very great gift.

As a Muslim, it is a form of faith and piety to Allah SWT. The Lord of the worlds is to guard, maintain and study and practice the holy book Al-Qur'an (kitabullah). Allah SWT. of course always maintain the purity and authenticity of the Qur'an, as His word in the Qur'an Surah Al-Hijr verse 9: 


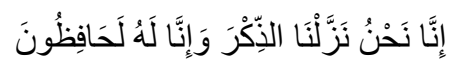

"Indeed, it is We who have sent down the Qur'an and surely We will maintain it." (Qs. AlHijr:9) (Shihab, 1994).

Becoming a memorizer of the Qur'an is the greatest dream for all Muslims. The best Muslims are those who study and study the Qur'an and practice it. As the Messenger of Allah said:

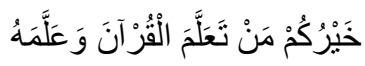

"The best among you are those who learn the Qur'an and teach it." (HR. al-Bukhari) (Rahman, 2016).

Making students as human beings who believe, have faith and fear God Almighty is one of the goals of national education. This is in line with the definition of education written in the legal umbrella of national education, namely Law Number 20 of 2003 concerning the National Education System which explains that :

Education is a conscious and planned effort to create a learning atmosphere and learning process so that students actively develop their potential to have religious spiritual strength, self-control, personality, intelligence, noble character, and skills needed by themselves, society, nation and state.

The functions and objectives of national education according to the 2003 Law on the National Education System are:

National education functions to develop capabilities and shape the character and civilization of a dignified nation in the context of educating the nation's life, aiming at developing the potential of students to become human beings who believe and fear God Almighty, have noble character, are healthy, knowledgeable, capable, creative, independent. , and become a democratic and responsible citizen.

From the explanation above it can be drawn to the conclusion that education is not only the general education of education but also the education of islam. Religious education in this case means the science of Islamic education, namely education based on the Qur'an and hadith. Islamic education contains a number of points or values contained in the Qur'an and the Sunnah of the Prophet which then move across generations through the education and teaching system. (Sofyan, Nursihah, \& Hambali, 2021).

Regulation of the Minister of National Education Number 22 of 2006 concerning Content Standards for Primary and Secondary Education Units, states that:

Religious education is intended to increase spiritual potential and shape students into human beings who believe and fear God Almighty and have noble character.

The implementation of the Tahfiz Al-Qur'an program is one form of the application of religious education. Tahfiz Al-Qur'an is a process where a person remembers, memorizes, implants the words of Allah in the heart. According to Wadji quoted by (Hidayah, 2016) Tahfiz Al-Qur'an is an activity of memorizing verses of the Qur'an so that the verse can be remembered by heart continuously according to the rules.

Memorizing the Qur'an as a form of implementing Islamic education must be instilled in elementary school-aged children as early as possible because elementary school children have a very strong memory, although of course in reading the word of Allah there are still many who are not fluent or not in accordance with the rules of recitation. . According to Abu Ahmadi and Munawar Sholeh quoted by (Ulum \& Ropikoh, 2018), at the age of about four years, a child's memory is in a steady phase and at the age of 8-12 years, the intensity of a child's memory is getting stronger so that age can contain more material. 
The habit of memorizing the Qur'an has been going on for a long time, even from the time of the Prophet, memorizing the Qur'an is one way to keep the authenticity of the Qur'an awake because the Qur'an was revealed gradually. In Indonesia, the tradition of memorizing the Qur'an has been going on for a long time, even memorizing the Qur'an has now been broadcast in the Indonesian hafiz program on private television stations. In addition, there are also Indonesian children who excel in the international arena in memorizing the Qur'an. Musa La Ode Abu Hanafi or known as Musa is a hafiz (memorizer of the Qur'an) from Indonesia who won 3rd place in the Musabaqoh Hifzil Qur'an (MHQ) competition in Egypt on April 10-14 2016. His young age, which is 7 years old, was able to beat other participants from various regions and of course from different age ranges, not even a few participants who were older than him' (sahabatkeluarga, 2016).

Musa's achievements show that anyone can and is able to memorize the Qur'an, even children who are still in elementary school or aged 7-12 years. Elementary school-age children are considered very capable of memorizing verses of the Qur'an quickly, this is in line with what was stated by Kerubun (2016) that the age of elementary school children is the golden age of a child, because at that age the child's brain will be very can quickly catch, store and issue something" (Kerubun, 2016).

Madrasah Ibtidaiyah is one of the educational institutions in Indonesia that is identical with learning based on the Qur'an and hadith in addition to general subjects. Based on data from the Ministry of Religion as of 2019/2020, it was recorded that the number of Ibtidaiyah madrasas in Indonesia amounted to 25,593, of which 23,884 were private Ibtidaiyah madrasas and the remaining 1,079 were state Ibtidaiyah madrasah..

If seen from the data, the number of private Ibtidaiyah madrasah is more than the number of public Ibtidaiyah madrasas because the average number of devotees is increasing every year. Then referring to data from the Ministry of Religion quoted by (Anwar, Suhendi, Sobandi, \& Sofyan, 2020), that in 2017 there were at least 4,500 Islamic educational institutions focused on studying the Qur'an, especially tahfiz Al-Qur'an, p. This proves that there is public interest in memorizing the Qur'an.. Taqwim \& Hidayat (2021), argue that private Ibtidaiyah madrasas are more in demand by the public because there is a lot of local and extracurricular content contained in the curriculum of education units or madrasas, especially superior programs with religious characteristics such as tahfiz AlQur'an.

It is undeniable that the Covid-19 virus pandemic has affected all aspects of life, including the world of education. The temporary closure of educational institutions as an effort to suppress the spread of the Covid-19 Virus has an impact on the implementation of the learning process, including the implementation of school programs including the tahfiz Al-Qur'an program.. Learning that was originally carried out face-to-face is now forced to be carried out virtually. One solution that is considered good enough to do is to do online learning. However, online learning can also be a problem because not all levels of society can adapt to online learning. Likewise, tahfiz Al-Qur'an which is carried out online, not all students can adapt to it because the ability to memorize different students and memorizing the Qur'an is a learning process that requires more special attention..

One of the formal educational institutions that accommodate the memorizers of the Qur'an who feel the impact is MI Terpadu Ar-Rifqi which is located in Cibiru Hilir, Cileunyi District, Bandung Regency. The Tahfiz Al-Qur'an program which has become an added value for madrasas in the last two years has undergone a change in the order in the implementation of its activities. Tahfiz program activities which are usually carried out face-to-face between students and tahfiz teachers in the classroom are currently changing 
to face-to-face online with the help of WhatsApp Video Call media. In connection with these problems, there are several things that are not yet known, namely how the implementation of the tahfiz program in the 2020/2021 school year which in the current school year is still being carried out online, what are the supporting and inhibiting factors of its implementation, then what is the implementation of the tahfiz program this year? the 2020/2021 lesson is effective in improving student memorization, because of course being a memorizer of the Qur'an at elementary school age requires special attention in improving and maintaining the fluency of memorization.

\section{Method}

This writing uses a qualitative descriptive method with a qualitative research approach and the type of case study research. The research subjects were tahfiz teachers and fifth grade students. The data in this writing were obtained from observations of the activities of tahfiz Al-Qur'an in class V (five) MI Terpadu Ar-Rifqi, interviews with school principals, vice principals for curriculum, tahfiz teachers and students, as well as documentation relevant to tahfiz programs such as recapitulation of rote data and daily notes of rote targets. The data that has been obtained is analyzed in three stages, namely reduction, presentation in narrative form and conclusions and verification. The effectiveness of the tahfiz program is obtained from the results of calculations using the percentage formula which is then categorized in the effectiveness percentage criteria table. The following formula is used to calculate the percentage of effectiveness along with the criteria for the percentage of the effectiveness of the tahfiz Al-Qur'an program in improving student memorization..

$$
\mathrm{P}=\frac{\mathrm{f}}{\mathrm{N}} \times 100 \%
$$

Description:

P : Percentage

$\mathrm{f} \quad$ : Frequency (number of students who reach the rote target)

$\mathrm{N}$ : The total number of respondents (the total number of students in class $\mathrm{V}$ (five)

Table 1 Criteria for Percentage of Effectiveness

\begin{tabular}{cc} 
Interval Scale & Description \\
\hline $0 \%-20 \%$ & Ineffective \\
\hline $21 \%-40 \%$ & Less effective \\
\hline $41 \%-60 \%$ & Neutral/Adequate \\
\hline $61 \%-80 \%$ & Effective \\
\hline $81 \%-100 \%$ & Very effective
\end{tabular}

(Riduwan, 2013)

\section{Results and Discussion}

3.1 Implementation of the tahfiz program at MI Terpadu Ar-Rifqi, Cileunyi District, Bandung Regency for the 2020/2021 Academic Year.

Madrasah Ibtidaiyah Integrated Ar-Rifqi is one of the educational institutions that implements memorizing the Qur'an. The tahfiz Al-Qur'an program at MI Terpadu Ar-Rifqi is a superior program that characterizes madrasas. The tahfiz program is implemented as a form of realization of the madrasa's motto, which is to make students with character, 
knowledge and achievements. The implementation of the tahfiz program at MI Terpadu Ar-Rifqi can be explained through the following elements.

\subsubsection{Purpose}

The tahfiz Al-Qur'an program at MI Terpadu Ar-Rifqi has been implemented since 2012 with the aim of producing a generation of Qur'anic people with good character. As stated by Rasyid (2015) that memorizing the Qur'an can purify the soul and cleanse the mind, by studying the Qur'an one can live in society and nation well, besides that the Qur'an can eradicate ignorance, poverty, suffering and injustice.

\subsubsection{Educator}

The implementation of the tahfiz Al-Qur'an program certainly involves educators who are experts in their fields to plan, manage and evaluate activities of tahfiz Al-Qur'an. The achievement of the goals of the tahfiz program and the success of students in memorizing and improving the memorization of the Al-Qur'an are influenced by educators (tahfiz teachers) who are competent in the field of Al-Qur'an science. The tahfiz teacher at MI Terpadu Ar-Rifqi in the 2020/2021 school year was considered ideal because it was focused only on teaching tahfiz, in contrast to previous years, namely the class teacher at MI Terpadu Ar-Rifqi concurrently serving as a tahfiz teacher due to lack of human resources ( HR) to teach tahfiz Al-Qur'an. There are six tahfiz teachers who teach at MI Terpadu Ar-Rifqi, four of whom guide class $\mathrm{V}$ (five). There are several special competencies that must be possessed by a tahfiz teacher at MI Terpadu Ar-Rifqi, namely the tahfiz teacher at MI Terpadu Ar-Rifqi must have the ability to read the Qur'an in accordance with tajwid and makharijul letters and must memorize the Qur'an. a minimum of chapters 30 , chapters 29 and chapters 28 . In addition to these two special competencies, tahfiz teachers at MI Terpadu Ar-Rifqi also have several other competencies that are the same as teacher competencies in general, namely: (a) tahfiz teachers at MI Terpadu ArRifqi able to carry out and manage the activities of tahfiz Al-Qur'an properly; (b) the tahfiz teacher at MI Ar-Rifqi has a personality of faith and piety to Allah SWT. have a noble character, look in accordance with Islamic religious law, be a role model for students, speak gently and politely, patiently and calmly and sincerely when teaching, always ready to serve students who will deposit memorization even outside of learning hours, and always reflect on themselves together with all tahfiz teachers regarding the shortcomings or strengths in teaching students; (c) the tahfiz teacher at MI Terpadu Ar-Rifqi can communicate politely and politely either orally, in writing or in gestures either with students or with other teachers; and (d) the tahfiz teacher at MI Terpadu Ar-Rifqi can master the tahfiz Al-Qur'an material well. As An-Nawawi quoted by (Rohmah, 2020) mentions that four competencies that must be possessed by a tahfiz teacher are commendable moral competence (personality competence), competence related to reading and memorizing the Qur'an (professional competence), habblu minannas competence (social competence) and muhallim competence (professional competence).

\subsubsection{Leaners}

The existence of students is the most important thing in the implementation of tahfiz Al-Qur'an because if there are no students, the tahfiz program will not run well. There are 53 students in class V (five) and they are divided into four tahfiz groups. This grouping is determined based on the students' ability to read the Qur'an not based on the ability or level of memorization of students. Overall, grade V (five) students have been able to take part in the tahfiz Al-Qur'an program well. One of the rights of students is to get religious education, through this tahfiz program students become fulfilled their rights. According to Setiawan quoted by (Lestari, 2020), among the rights of students according to 
Indonesian Law no. 20 of 2013 is to obtain: (a) religious education in accordance with their religion; (b) educational services in accordance with talents, interests and abilities; (c) scholarships for high achievers and their parents cannot afford it; (d) move to an educational program on an equivalent educational track and unit; and (e) complete education in accordance with their respective learning speed and do not deviate from the stipulated time limit.

\subsubsection{Content}

Learning materials are cognitive, pricomotor and affective that must be mastered by students in order to achieve predetermined competency standards (Iriani \& Ramadhan, 2019). The material in the tahfiz program is the target of the Al-Qur'an letters that must be completed by students within a predetermined period of time. At MI Terpadu Ar-Rifqi the material for tahfiz Al-Qur'an is determined by the madrasa, the material is letters that must be completed at least by students in one semester. Each student is required to complete the minimum target of the letter that has been determined, but if you don't reach the target or exceed the target, it's okay because you come back with the ability to memorize students. The minimum surah that must be completed by fifth grade students in even semesters are At-Tahrim, At-Talaq, At-Taghabun and Al-Munafiqun letters.

\subsubsection{Method}

The tahfiz program at MI Terpadu Ar-Rifqi does not use one specific method, but instead combines several methods in each tahfiz Al-Qur'an activity. The first method is that students only use one manuscript. Memorizing the Qur'an by using a special manuscript is considered effective because it is easier to give an impression in memory, each page that is read will provide an overview and will be easier to remember if there is a forgotten memorization. (Makhyaruddin, 2013). The Qur'an used by the students of MI Terpadu ArRifqi is the Al-Qur'an Al-Hufaz, which can be seen in the following picture.
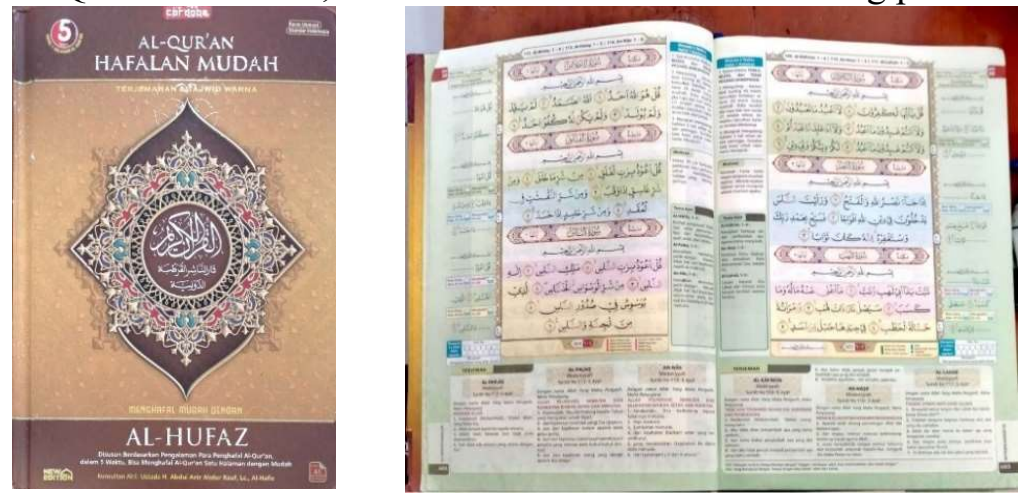

The second method used by Ar-Rifqi's Integrated MI students in memorizing the Qur'an is the tahfiz teacher exemplifies repeatedly reading the verses that students want to memorize, students listen and imitate until the reading is correct then the tahfiz teacher gives time to memorize. This method is actually the same as the talaqqi method. it's just that in MI Terpadu Ar-Rifqi it's called technique two and three. According to Makharuddin (2013) the existence of a tahfiz teacher plays an important role in the application of the talaqqi method because with this method the tahfiz teacher must give an example of the pronunciation of the verses of the Qur'an to be memorized. The talaqqi method can be defined as the way students memorize the Qur'an by listening to the reading of the verses 
of the Qur'an read by an expert teacher repeatedly with the aim that students can read the verse correctly and can memorize it well.

The third method applied to the tahfiz program at MI Terpadu Ar-Rifqi is the muraja'ah method. Students always praise their memorization at the beginning of the tahfiz activity with the tahfiz teacher who guides them. The muraja'ah method is an effort made by a memorizer of the Qur'an by repeating his memorization to avoid forgetting and making mistakes (Ilyas, 2020). Broadly speaking, the reason why someone forgets the verses that have been memorized is that they often forget because their enthusiasm is not renewed and it is difficult to remember things because they are hindered by new memorization that clash with each other. (Alfatoni, 2019).

3.1.6 Evaluation

Evaluation can be interpreted as a process of providing information that can be used as a consideration for something from various things in determining a decision (Ananda \& Rafida, 2017). The evaluation of the tahfiz program at MI Terpadu Ar-Rifqi was carried out by a tahfiz teacher. The evaluations carried out included student attendance, student reading quality (tajwid and makharijul letters), memorization fluency, achievement of memorization targets and things that hindered the tahfiz program and the solutions. Evaluation of the tahfiz program at MI Terpadu Ar-Rifqi consists of daily evaluations, weekly evaluations and semester evaluations (PTS and PAS). Daily evaluations are carried out at every meeting of tahfiz Al-Qur'an. The tahfiz teacher will record the students' memorization progress at each meeting. If the student's memorization is felt to be strong and fluent, the tahfiz teacher will suggest to continue memorizing to the next verse. Meanwhile, if students' memorization is still not fluent, the tahfiz teacher will continue to ask students to repeat the same verse that is being memorized until they are completely memorized. The weekly evaluation is carried out by the tahfiz teacher by looking at the progress of students' memorization over the past week, whether there is an increase or decrease. Tahfiz teachers analyze each other what the problem is, whether the problem is caused by the tahfiz teacher or by the students. This was analyzed by fellow tahfiz teachers and sought a solution together. Semester evaluation is carried out with the Mid-Semester Assessment (PTS) and Final Semester Assessment (PAS). PTS and PAS are carried out in the form of tahfiz exams. The assessment criteria for the tahfiz exam include recitation, makharijul letters and fluency in memorization. Students are tested for memorization according to the number of letters they have successfully memorized, the tahfiz test is carried out on the first verses, middle verses and final verses of the surah.

3.2 Faktor Factors supporting and inhibiting the implementation of the tahfiz program at MI Terpadu Ar-Rifqi, Cileunyi District, Bandung Regency for the 2020/2021 Academic Year.

Faktor Factors supporting the implementation of the tahfiz program at MI Terpadu Ar-Rifqi include several things. First, interest and motivation in students to memorize the Qur'an. The existence of a willingness or interest in students is very important in the continuity of the process of teaching and learning activities including the tahfiz Al-Qur'an program. Interest is one of the important components that must exist in students, with a strong interest in learning to make students learn without feeling forced (Suzana \& Jayanto, 2021). In addition, students' motivation or awareness of the importance of memorizing the Qur'an is a supporting factor for the implementation of the tahfiz program. Students' awareness is present because of a strong interest in memorizing the Qur'an, besides that the tahfiz teacher imparts knowledge about the importance of memorizing the Qur'an and the virtues obtained by a memorizer of the Qur'an which makes students know 
the benefits of memorizing the Qur'an. memorize the Qur'an. Sayyid (2013) explains that people who will succeed in memorizing the Qur'an are those who have strong determination, strong spirit, patience and istiqamah and knowledge of the virtues of memorizing the Qur'an. Second, students always practice memorizing the Qur'an and keeping it memorized. Class V (five) students always practice memorizing the Qur'an and doing muraja'ah in their spare time, school holidays or after praying. According to Husamah et al (2018), effective learning is learning that is accompanied by practice. The exercise can be in the form of re-learning the material that has been studied, recalling and reviewing again so that the material that has been studied can be mastered well. As with studying the Qur'an, someone who studies the Qur'an in any form including memorizing it must always practice so that what he has learned becomes meaningful so that it cannot be easily forgotten. The third supporting factor is the tahfiz teacher. Teachers are components that have a major role in the success or achievement of educational goals (Sidik, 2016). Tahfiz teachers at MI Terpadu Ar-Rifqi can be said to be professional teachers because they have several competencies that a tahfiz teacher should have. These competencies include commendable moral competence, competence to read and memorize the Qur'an, competence of habblu-minannas, and competence of Muslim converts. In addition, the tahfiz teacher at MI Terpadu Ar-Rifqi also acts as a motivator and mentor who is always ready to serve students in memorizing the Qur'an. the fourth supporting factor is the supporting facilities. The facilities owned by all students that support the achievement of the goals of the tahfiz program are the Al-Hufaz manuscript of the Qur'an, devices used for video calls with tahfiz teachers, and internet quota. Components that can support virtual learning are devices, credit, quotas and a good and stable internet network (Putria, Maula, \& Uswatun, 2020).

The inhibiting factors for the implementation of the tahfiz program at MI Terpadu Ar-Rifqi are first, the lack of face-to-face time. The duration of time provided for the implementation of the online tahfiz Al-Qur'an program is considered insufficient. The duration given to carry out the tahfiz program in class V (five) MI Terpadu Ar-Rifqi is two hours, starting at 08.00 WIB until 10.00 WIB. Kyriacou quoted by (Setyosari, 2014) argues that a learning can be said to be effective if there are two main things, namely active learning time (active learning time) and quality of instruction (learning quality). The first point is the amount of time devoted by students during teaching and learning activities. Second, the feeling of laziness, laziness is caused by students who prefer to play with friends, play games on their cellphones, watch television, watch movies or YouTube on their cellphones. There are strategies carried out by tahfiz teachers and students to overcome this feeling of laziness such as re-aligning intentions, determined to be serious about memorizing, ablution and drinking water so that when memorizing the Qur'an is not sleepy. In addition, the tahfiz teacher always motivates students at every meeting and gives appreciation so that students continue to be enthusiastic about memorizing the Qur'an. In connection with this problem, there are some tips that can be done by tahfiz teachers or parents to raise students' enthusiasm for learning so they are not lazy to memorize the Qur'an while the tahfiz program is carried out online. The strategies/methods are (1) creating learning readiness; (2) provide motivation; (3) reduce excessive anger; (4) create harmony; (5) provide guidance; (6) inserting humor as a learning transition; (7) evoke the effect of shame; and (8) giving gifts (Warif, 2019). The third inhibiting factor is the internet connection/network. As long as the tahfiz program is carried out online, the internet connection/network must be stable so that the implementation of the tahfiz program can run well because poor internet connection/network is one of the causes of 
delays in the implementation of the tahfiz program. A bad internet connection can be caused by several things such as bad weather, geographical location or interference with the internet provider. Based on the results of the study, it was found that when students were reciting verses that they had memorized, sometimes the tahfiz teachers did not hear the reading clearly because of the poor internet network. Likewise, when the tahfiz teacher is providing corrections to student readings, the corrections or directions are not clearly and correctly caught by the students. To overcome this problem, the tahfiz teacher sends a voice message containing examples of reading verses of the Qur'an in accordance with the target of student memorization and corrections or things that students must correct from reading and memorizing. As Suhayman et al (2020) Signals or internet connections can affect online teaching and learning activities, because the area where students live has different signal strengths. Then the fourth inhibiting factor is parents. The lack of parental roles such as busy parents, lack of support and motivation during the implementation of tahfiz Al-Qur'an is one of the causes of delays in the implementation of the tahfiz program at MI Terpadu Ar-Rifqi. The parent factor plays a very essential role in the student learning process, whether learning is carried out face-to-face in class or online. Learning difficulties and student learning progress are caused by the lack of parental attention to their children's education and the uncaring attitude that appears so that children's learning progress is not noticed. (Nurjan, 2016).

3.3 Effectiveness of the tahfiz program in improving the memorization of grade $\mathrm{V}$ (five) students at MI Terpadu Ar-Rifqi for the 2020/2021

The effectiveness of the tahfiz program in improving the memorization of grade $\mathrm{V}$ (five) students at MI Terpadu Ar-Rifqi for the 2020/2021 school year can be seen from two aspects. First, when viewed from the aspect of the large number of students who have increased their memorization of letters, the implementation of the tahfiz program in class $\mathrm{V}$ (five) of the Integrated MI Ar-Rifqi for the 2020/2021 academic year is $100 \%$ effective or in the very effective category. Second, when viewed from the aspect of the large number of students who achieved the letter memorization target determined by the madrasa, the implementation of the tahfiz program in class V (five) of the Integrated MI Ar-Rifqi in the $2020 / 2021$ school year was in the very ineffective category because there were only 7 students who achieve the target or only $13.2 \%$ of the total 53 students

Based on the results of these calculations and also based on the results of interviews, it was concluded that the Covid-19 pandemic greatly affected the effectiveness of the tahfiz Al-Qur'an activities in improving students' memorization of the Qur'an, because before Covid-19 almost $80 \%$ of students could reach the predetermined target. The number of class $\mathrm{V}$ (five) students who were able to achieve the memorization target was only 7 of the total number of class V (five) students of 53 people, this proves that the tahfiz Al-Qur'an program implemented during the pandemic period is very ineffective in achieving the target of letters. letter that should be achieved by students. According to Akhirudin, et al (2019), effective learning activities can be seen from the goals achieved by students within a certain period of time. In this regard, the learning activity in question is the implementation of the tahfiz Al-Qur'an program and the aim is a number of letters that must be memorized by class V (five) MI Terpadu Ar-Rifqi in the even semester of the 2021/2021 academic year.

\section{Conclusion}


The implementation of the tahfiz Al-Qur'an program at MI Terpadu Ar-Rifqi includes objectives, educators, students, materials, methods and evaluations. The implementation of the tahfiz program in class V (five) MI Terpadu Ar-Rifqi is supported by several factors, namely the interest and motivation in students to memorize the Qur'an, students always practice memorizing the Qur'an and keep it memorized, the tahfiz teacher and supporting facilities. While the inhibiting factors are the lack of face-to-face time, laziness, internet connection/network and parents. The effectiveness of the tahfiz program in class V (five) of the Integrated MI Ar-Rifqi is in the category of very effective in improving letter memorization and very ineffective in achieving memorization targets based on tahfiz material.

\section{References}

Alfatoni, S. (2019). Teknik Menghafal Al-Qur'an Secara Cepat. Semarang: Mutiara Aksara.

Ananda, R., \& Rafida, T. (2017). Pengantar Evaluasi Program Pendidikan. Medan: PERDANA PUBLISHING.

Anwar, C., Suhendi, S., Sobandi, O., \& Sofyan, M. (2020). Pengembangan Tahfizh AlQur'an: Metode, Media, dan Evaluasi. KTI UIN Sunan Gunung Djati Bandung.

Drajat, A. (2017). Ulumul Qur'an Pengantar Ilmu-ilmu Al-Qur'an. Jakarta: Kencana.

Hidayah, N. (2016). Strategi Pembelajaran Tahfidz Al-Qur'an di Lembaga Pendidikan. Ta'allum Jurnal Pendidikan Islam, Vol. 4, No. 1.

Hitami, M. (2012). Pengantar Studi Al-Qur'an: Teori dan Pendekatan. Yogyakarta: LKiS Yogyakarta.

Husamah, Pantiwati, Y., Restian, A., \& Sumarsono, P. (2018). Belajar \& Pembelajaran. Malang: UMMPRESS: Universitas Muhammadiyah Malang.

Ilyas, M. (2020). Metode Muraja'ah dalam Menjaga Hafalan Al-Qur'an. Al-Liqo: Jurnal Pendidikan Islam, Jilid 5, No. 01.

Iriani, T., \& Ramadhan, A. (2019). Perencanaan Pembelajaran Untuk Kejuruan. Jakarta: Kencana.

Kerubun, A. (2016). Menghafal Al-Qur'an dengan Menyenangkan. Yogyakarta: CV. ABSOLUTE MEDIA.

Lestari, D. E. (2020). Perkembangan Peserta Didik Sekolah Dasar. Sekaran: Pustaka Taman Ilmu.

Makhyaruddin, D. M. (2013). Rahasia Nikmatnya Menghafal Al-Qur'an Berdasarkan Pengalaman Penulis Tentang Menghafal Al-Qur'an dalam 56 Hari. Jakarta Selatan: Noura (PT Mizan Publika).

Nurjan, S. (2016). Psikologi Belajar. Ponorogo: WADE GROUP.

Putria, H., Maula, L. H., \& Uswatun, D. A. (2020). Analisis Proses Pembelajaran dalam Jaringan (DARING) Masa Pandemi Covid- 19 Pada Guru Sekolah Dasar. JURNAL BASICEDU: Journal of Elementary Education, Volume 4, Nomor 4 .

Rahman, A. (2016). 1/2 Jam Sehari Bisa Baca \& Hafal Al-Qur'an. Jakarta: Shahih.

Rasyid, M. M. (2015). Kemukjizatan Menghafal Al-Qur'an. Jakarta: PT Elex Media Komputindo.

Riduwan. (2013). Skala Pengukuran Variabel-variabel Penelitian. Bandung: Alfabeta.

Rohmah, W. (2020). Urgensi Kompetensi Guru Tahfidz dalam Meningkatkan Prestasi Menghafal Al-Qur'an Siswa. Sawabiq: Jurnal Keislaman, Vol. 1, No. 1.

sahabatkeluarga. (2016). Musa, Juara Internasional Penghafal Qur'an "Menjadi Juara Karena Didikan Keluarga". sahabatkeluarga.kemendikbud.go.id. 
Sayyid, S. A. (2013). Balita pun Hafal Al-Qur'an (Pengantar: Ust. Muhammad Arifin Ilham). Solo: Tinta Medina.

Setyosari, P. (2014). Menciptakan Pembelajaran yang Efeketif dan Berkualitas. Jurnal Inovasi dan Teknologi Pembelajaran, Volume 1, Nomor 1.

Shihab, Q. (1994). Membumikan Al-Quran: Fungsi dan Peran Wahyu dalam Kehidupan Masyarakat. Bandung: MIzan.

Sidik, F. (2016). Guru Berkualitas untuk Sumber Daya Manusia Berkualitas. TADBIR: Jurnal Manajemen Pendidikan Islam, Vol. 4, No. 2.

Sofyan, M., Nursihah, A., \& Hambali, H. (2021). Nilai-nilai Pendidikan Islam dalam Novel Adzra' Jakarta Karya Najib Kailani. ATTHULAB: Islamic Religion Teaching \& Learning Journal, Volume 6, Nomor 1.

Suzana, Y., \& Jayanto, I. (2021). Teori Belajar \& Pembelajaran. Batu: Literasi Nusantara.

Syarbini, A., \& Jamhari, S. (2012). Kedahsyatan Membaca Al-Qur'an. Jakarta Selatan: RuangKata Imprint Kawan Pustaka.

Taqwim, M., \& Hidayat, S. (2021). Model Pembelajaran Tahfidz Di Masa Pandemi Covid19 Di MIM Karanganyar Dan Mim Margomulyo Matesih Kabupaten Karanganyar. Surakarta: Universitas Muhammadiyah Surakarta.

Ulum, M. S., \& Ropikoh, I. (2018). Upaya Meningkatkan Daya Ingat Anak Melalui Metode One Day One Hadits Pada Anak Usia TK (Di Madrasah Baitul Hikmah Naringgul Tegallegaa Bungbulang Garut). WALADUNA: Jurnal Pendidikan Islam Anak Usia Dini, Vol. 1, No. 2.

Warif, M. (2019). Strategi Guru Kelas dalam Menghadapi Peserta Didik yang Malas Belajar. TARBAWI: Jurnal Pendidikan Islam Fakultas Agama Islam Universitas Muhammadiyah Makassar, Vol. 4, No. 01. 